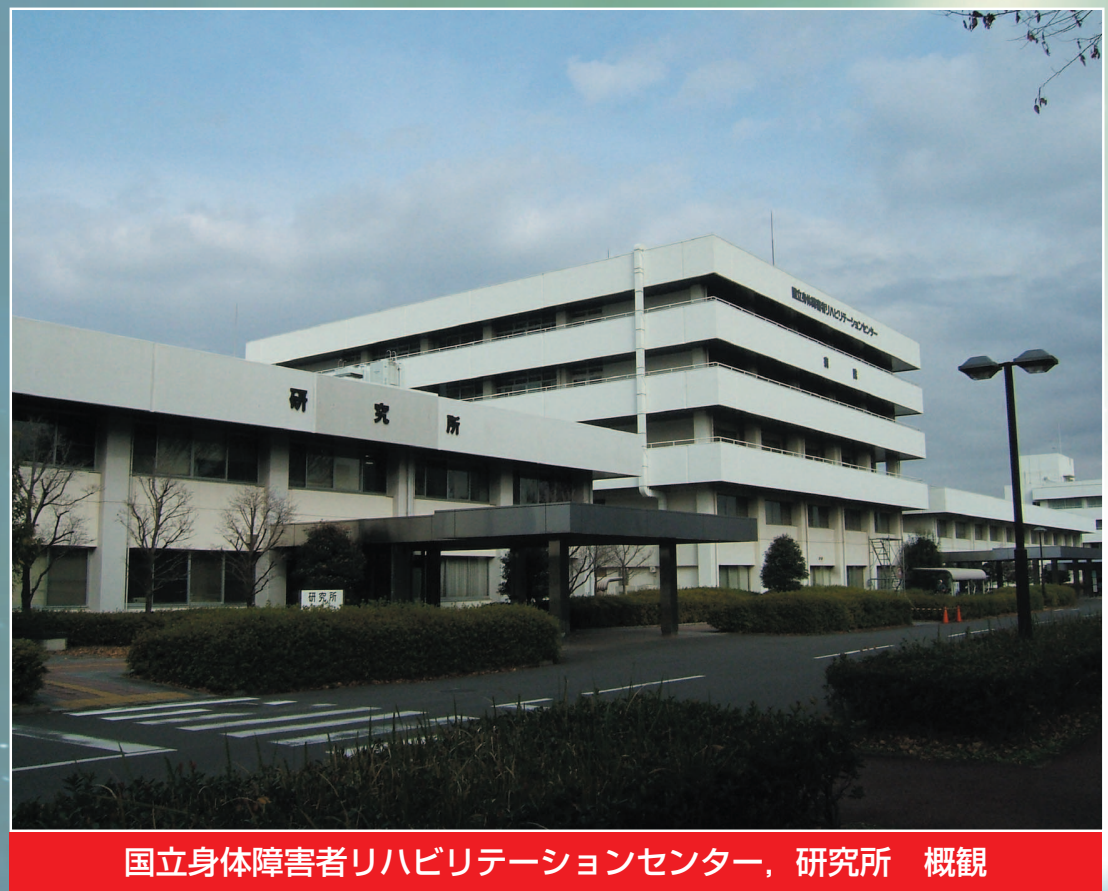

Gravure \& Interview 精密工学の最前線

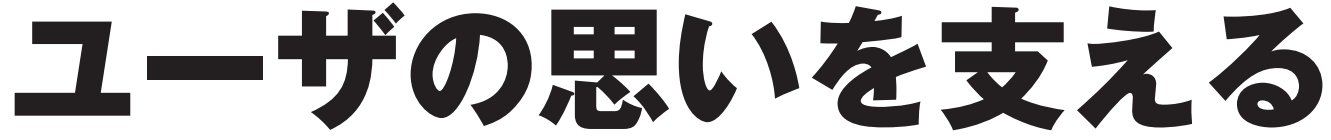
福祉機器の開発と評侕

国立身体障害者リハビリテーションセンター 研究所 福祉機器開発部

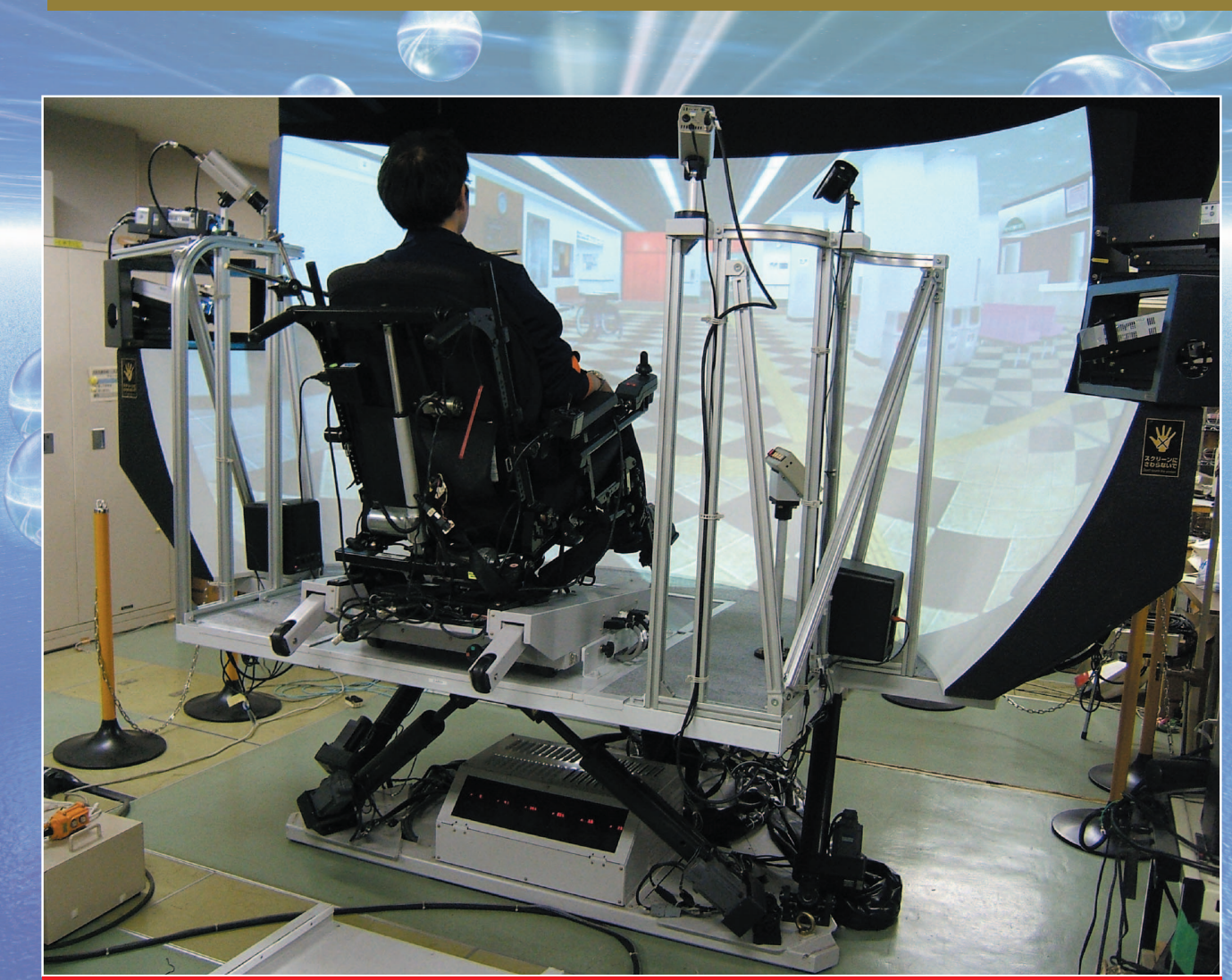

車いすシミュレータ 

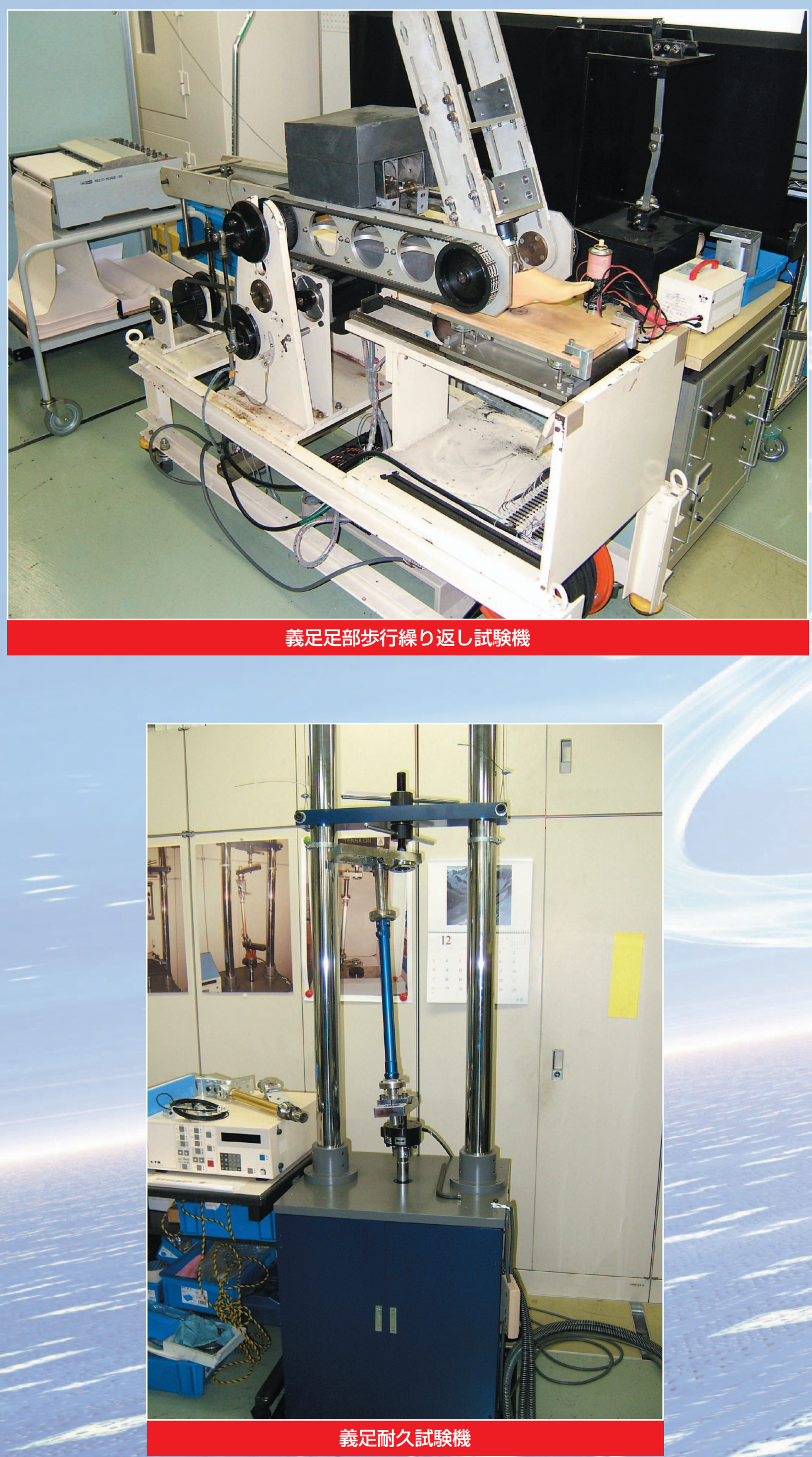
Q 国立身体障害者リハビリテー ションセンターの概要についてお聞か せ下さい.

井上厚生労働省直轄の施設で, 障 害のある方々に福祉・医療の面から総 合的なリハビリテーションサービスを 提供するとともに, 研究や人材育成を 行い, 障害者の自立生活, 社会参加の 推進に寄与することを目的として，昭 和 54 年に設立されました。開設当初 は身体障害のみを対象としていました が, 最近では高次脳障害等, 認知・知 的障害へと範囲を拡げています。主と して, 更生訓練所, 病院, 学院および 研究所からなります.

\section{Q 研究所の概要と特徵について} お聞かせ下さい.

井上本研究所では, 障害者の自立 と社会参加・QOL の向上を支えるリ ハビリテーション研究を行うことをミ ッションとしています。研究の柱は 4 つあります。1つ目は, 病院や更生訓 練所と協力して臨床の現場に密着した 研究を行うことです，歩行訓練などの リハビリテーション技術の開発や裖瘡 の発生を抑え安定した座位を取ること のできるシートや車いすの適合に関す る研究などに代表される, 個々の障害 者に合わせた訓練方法や機器に対する 取り組みを行っています。2つ目は, 社会参加を促進する技術に関する研究 で，ジョイスティックなど通常の電動 車いすを操作するための機器が使えな い重度障害者のために，音声や身振り や筋電など，人によって違う使える能 力を活用する車いすの開発など, 支援 のための技術開発を行っています。3 つ目は, リハビリテーション研究の世 界中核研究所を目指した活動で，ISO やWWWCなどの国際標準作成への 貢献や，研修などの国際協力を行って います。4つ目は，国の障害者政策を 推進するための活動で, 行政課題の研 究や政策立案に向けた研究成果の提供 を行っています。高次脳機能障害支援 普及事業などはその良い例です。

\section{ユーザの思いを支える福补機器の開眵と評侕}

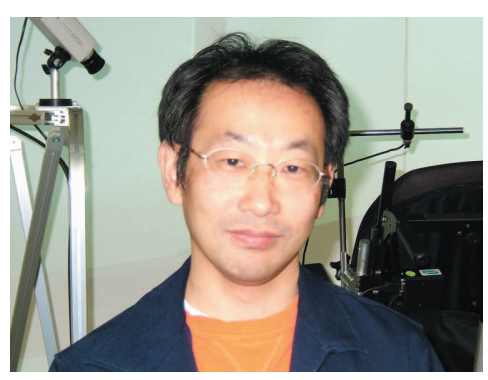

井上 剛伸 氏
国立身体障害者りハビリテーションセンター福祉线器開発部、

福社機器開発室長并上 剛伸 氏 第一福社機器試呀䛨価室長 相川 孝訓 氏

インタビュア/東京工業大学 武田 行生
世界的にも，これだけ総合的にリハ ビリテーションを扱っている研究所は 数が少ないのが現状です。しかも， 6 つの部のうち 2 つ部が工学系です が, このように, リハビリテーション の研究に工学を重要視していることも 本研究所の一つの特徴です

研究所全体で, 常勤で研究活動にあ たる職員は 27 名で,さらに 3 年任期 の流動研究員が 20 人程度います。

\section{Q 福祉機器開発部の概要と特徵 についてお聞かせ下さい.}

井上 福祉機器開発部では, 新しい 福祉機器を作ることとその評価が守備 範囲です。福祉機器開発部で開発した 具体的な福祉機器としては, 重度障害 者用電動車いす, 電動車いすシミュレ ー夕, 視線入力式コミュニケーション 装置などです。また，個々のユーザに 対する既存の福祉機器の適合性を調心 て評価するシステムの構築も本開発部 の重要なテーマです，週に 1 回本セン ターの病院では，それぞれの方に適し た車いす，座位保持装置などを選択す るためのシーティングクリニックを実 施しています。そこでは, 福祉機器開 発部のスタッフも, 協力してサービス を行っています。研究所で開発した電 動車いすの臨床応用も実践していま す.

相川 第一福祉機器試験評価室では, 義足の足部の耐久試験機や義足の耐久 試験機などの開発と依頼試験の実施お
よびISO や JIS などの規格作成に関 する仕事を行っています. 当試験評価 室で開発した義足足部の耐久試験機 は, 実際の歩行に近い条件を出すよう に足部が動くようになっています。耐 久試験の回数は 100 万回で 2 ヶ 月く いの期間を要します。

井上このように, 福祉機器の開発 と評価を同等に重視している点は本開 発部の最大の特徵であり, かつ国内の 福祉工学関係の研究機関とは際立った 違いと言えます。

Q 福祉機器開発室の最近の研究 についてお聞かせ下さい.

井上主に重度障害者を対象とした 福祉機器の開発を行っています。

重度障害者の場合, 本人および家族 が，本人が何かを実行することを諦め ているケースが多々あります。この諦 めを何とか克服したいと思いました。 本人が「したいこと」と「できるこ と」を尊重し，その「できること」を 最大限に活かして自立を支援する「も の」を作ろうということです。このコ ンセプトに基づくプロジェクト「障害 者の安全で快適な生活を支える技術開 発」が科学技術振興調整費の重要課題 解決形研究プログラム (平成 16 年度 〜18 年度）に採択されました。多岐 にわたる症状を持ち,「できること」 が非常に限られている重度障害者に対 して適切な技術開発を行うことがポイ ントです. 


\section{Q このプロジェクトの概要をお 聞かせ下さい.}

井上 2 つのサブテーマからなって おり，私は「重度障害者の自立移動を 支援する技術の開発」を担当していま す。これは，国立身体障害者リハビリ テーションセンター研究所, 産業技術 総合研究所および東京大学による共同 研究で, 重度の障害がある方々にも気 軽に電動車いすを利用していただき， 積極的な社会参加を進めることが目的 です，いくつか具体的に説明します。

脳性マヒ等で手脚が不自由でも言葉 を話すことができる人は多くいます。 彼らは音声認識技術を本当に必要とし ているにもかかわらず，現在の音声認 識技術の開発は，その方向を向いては いません，本プロジェクトでは，ユニ バーサル符号系という音素よりも細か い音声表記の技術と, 雑音を除去する マイクロフォンアレイの技術を駆使 し, 脳性マヒ者の声で電動車いすが操 作できるシステムを開発，実証してい ます。

操作が不確実な場合でも, 電動車い す自体が安全性を確保できれば，重度 障害者の行動範囲を格段に拡げること が可能です，全天周の画像と距離の情 報を取得できる全方位ステレオカメラ システムを駆使して, 検出しにくい段 差や人など，周りの障害物の危険度を 考慮した危険回避を可能とするシステ ムの開発を行っています。この技術は まさに基礎開発が終わった段階の最新 技術で，とても過酷な使用環境である 電動車いすに対する応用開発を行うこ とで技術としても完成度が増し，さら に多くの応用につながる技術として開 発が進んでいます。

電動車いすに興味はあるけれども抵 抗があるという方に,「やってみたい を実現する」のコンセプトで電動車い すシミュレータを開発しました。これ は, 大型の球面スクリーンと衝撃や傾 斜を表現する動摇台により電動車いす 操作の臨場感あふれる擬似体験を実現 します，本気で操作しょうとすること で，その人の「できる力」また，本人
にも気がつかなかった「隠れた力」を 引き出し，シミュレー夕を操作しなが ら最適な入力装置を探します。また, 実際に生じ得る衝突による衝撃なども 体感できるようになっています。

\section{$\mathbf{Q}$ 福祉機器の研究開発で大事な ことを教えて下さい.}

井上 重度障害者の数は少ないので, 研究として出口管理をされてしまうと 若干つらいところがあります。しか し，重度障害者の限られた「できるこ と」でこれだけのことが実現できるん だということを社会に広め, 社会すな わち国を動かしたいと思っています。 その原動力は当事者である障害者の方 が握っており，それを促すことが我々 の仕事です.

今回のプロジェクトで開発した, 重 度障害者を対象とした電動車いすを福 祉機器展で展示したところ, 多くの重 度障害者から“自分にももっと可能性 があると思った”との声を聞くことが できました，そして，脳性マヒの女性 が，一度はあきらめた電動車いすの使 用をもう一度やってみようと思ってく れて，当病院のシーティングクリニッ クの対応により電動車いす操作を実現 した例がありました。

最近，認知症のある方を対象とした 福祉機器の開発を始めました，我々の コンセプトは，本人の自立を促すため に「もの」をうまく使抢うということ です。認知症により問題行動を起こす ことに対して，今までは仕方ないこと と見られてきました。 しかし，問題行 動の理由はそれぞれ異なっているもの の必ずあります。そこで，記憶を補つ たり，不安を解消するようなケアをす ると, 問題行動が減って来ることがあ ります。 このことは, 認知症者の施設 での研修から，本人のことを継続的に 見た結果わかったことです，要は，福 祉機器の研究開発の場合, 現実に起こ っていることを肌で感じて実施するこ とが重要です，本当にユーザの生活の 中で使える「もの」を作るために, で きる限りユーザと共に研究を進めてい
くことが大切と思っています

上述のプロジェクトで開発を進めて いる頭部ジェスチャ認識の電動車いす を例にとってみます。顔の真正面にカ メラを置き，それを用いて頭部の動き の検出が実現できたとしても, それは 画像認識技術の実験検証にしかなりま せん，ユーザの立場に立てば, 顔の正 面にカメラがあると操作の邪魔になり ますし，乗り移りのことを考えると， カメラを置けるのはアームサポートの 端の辺りになってしまいます。このよ うな条件下で機能する技術が求められ るのです。このようなことから, 我々 のスローガンは「ユーザの思いを支え る福祉機器の開発と評価」としていま す.

\section{Q これからの展開について教え} てください.

井上 重度障害者を対象とした福祉 機器の研究は, 当研究所ならではの特 徵的な研究であり, さらに進めていく ことを考えています。また, その数が 年々増加しており，社会的にも大きな 問題となっている認知症者を対象とし た福祉機器の研究を新たに展開してい くことも考えています. 先日, シンポ ジウム「認知症のある人の福祉機器— 生活の質を向上させるための「もの」 の活用と機器開発一」を本リハビリテ ーションセンターで開催しました。 100 名程度の参加者があり, 認知症に 対して「もの」を効果的に活用でき る，といった情報が入りつつありま す. 認知症と「もの」という切り口で 研究を進めている機関はまだ少なく， 国立の研究所として核になるような活 動を短期的ではなく長期的に進めて行 こうと考えています。 